МРНТИ 03.20.00

\title{
Байбулсинова А.С.
}

к.и.н., доцент кафедры Истории РК, Западно-Казахстанский государственный университет имени М. Утемисова,

Казахстан, г. Уральск, e-mail: alfia_b11@mail.ru

\section{ААУАЕТШАХ КУСЕПКААИЕВ - ОАИН ИЗ ПЕРВЫХ ОБРАЗОВАННЫХ ВРАЧЕЙ В КАЗАХСТАНЕ, УЧАСТНИК АВИЖЕНИЯ АААШ}

\begin{abstract}
В статье рассматривается общественно-политическая жизнь одного из первых образованных казахских врачей А.Кусепкалиева, участника движения Алаш-Орды в Западном Казахстане. На формирование общественно-политических взглядов А. Кусепкалиева повлияли общественнополитические события в России, гАе он учился, а также социально-экономическая и политическая жизнь казахского общества, откуда он и вышел. Общественно-политические деятели, находясь в гуще всех событий, сыграли важную роль в историческом процессе. И это при решении государственных вопросов не смогло не повлиять на А. Кусепкалиева.

Кмючевые слова: общественный деятель, врач, потомок Абулхаир хана, Алашорда, политическая репрессия.
\end{abstract}

\section{Baibulsinova A.S.}

Candidate of Historical Sciences, Docent, Makhambet Utemisov

West Kazakhstan State University, Kazakhstan, Uralsk, e-mail: al a_b11@mail.ru

\section{Dauletshakh Kusepkaliyev - one of the first educated doctors in Kazakhstan, participant of movement of Alash}

The article discusses the social and political life of one of the first educated Kazakh doctors D. Kusepkaliev, a participant in the Alash-Orda movement in Western Kazakhstan. The formation of the socio-political views of D. Kusepkaliyev was influenced by the socio-political events in Russia, where he studied, and on the other - the socio-economic and political life of Kazakh society, from which he emerged. The exchange of experience of individuals as social and political figures, being in the midst of all events, played an important role in the historical process. And this, while solving state issues, could not help but influence D. Kusepkaliyev.

Key words: public figure, doctor, descendant of Abulkhair Khan, Alashordy, political repression.

\author{
Байбулсинова А.С. \\ т.ғ.к., ҚР тарихы кафедрасының доценті, \\ М. Өтемісов атындағы Батыс Қазақстан мемлекеттік университеті, \\ Қазақ,стан, Орал қ., e-mail: alfia_b11@mail.ru \\ Қазақстандағы алғашқы жоғары білімді дәрігер және \\ Алаш қайраткерлерінің бірі - Аәулетшах Күсепқалиев
}

Мақалада қазақ даласындағы алғашқы жоғары білімді дәрігер әрі Алаш қайраткері А. Күсепқалиевты қоғамдық-саяси өмірі қарастырылған. А. Күсепқалиевты қоғамдық-саяси көзқарастарының қалыптасуына, біріншіден, өзі оқыған Ресейдегі саяси жағдайлар әсер етсе, екінші жағынан, оның өзінің шыққан ортасы, қазақ қоғамындағы болып жатқан өзгерістер әсер етпей қоймады. Сол замандағы саяси аласапыран барысында айналасындағы көзі қарақты зиялы қауыммен араласуы, оның өмірінің түбегейлі тарихи бетбұрысын өзгертті. Е^ үшін маңызды шешімдер қабылданған жауапты кезеңде қайраткер А. Күсепқалиев зор үлес қосты.

Түйін сөздер: қоғам қайраткері, дәрігер, Әбілқайыр ханның ұрпағы, Алашорда, саяси қуғынсүргін. 


\section{Введение}

В истории казахского народа среди общественных деятелей особое место занимает Кусепкалиев Даулетшах, один из первых врачей с высшим образованием, выпускник Московского императорского университета европейского образца.

Даулетшах (Даулетше) родился 23 (25) августа 1874 года в уезде Калмыково Уральской области в семье аристократов. На самом деле, Даулетшах Кусепкалиев родился в 1870 году в городе Старосербск уезда Екатеринослав. По данным алашоведа Д.Сулейменовой, которая опирается на материалы Государственного Центрального архива КазССР по истории формирования Жымпиты и о первом казахе, получившем звание профессора, Халеле Досмухамедове, о Даулетшахе Жусупулы Кусепкалиеве, пишет, что в тот год, когда родился Даулетшах, его отец Жусуп был сослан в ссылку в Сибирь. К моменту возвращения Жусупа на родину Даулетшаху было 10 лет. Он из рода Торе, в том числе потомок Нуралы хана. Дед родился от Ормана, сына Нуралы (Сулейменова, 2007: 142-147).

Даулетшах Кусепкалиев из ханского рода, является потомком известного хана Младшего жуза XVIII века Абулхаир хана. Об этом свидетельствуют документы, имеющиеся на руках его внучки Раисы Касабулатовой, также материалы, специально запрошенные из архивов России. В копии метрического свидетельства, данной Р. Касабулатовой, написано: «Дано сіе свидътельство Султану Юсуфгирею Кусябгалиеву Нуралиханову въ томъ, что отъ законного брака Султана Юсуфгирея и его супруги Хадиши, въ 1874 году 25-го августа родился сынъ Давлетшахъ Кусябгаліевъ Нуралиханов...» (Касабулатова, 2014: 1) .

Его имя в различных источниках пишется по-разному: Даулетше, Даулетшах, Даулет, однако правильным именем Кусепкалиева является Даулетшах. Дед Даулетшаха Кусепкалиева был сыном Кусепкали Орманова.

От Кусепкали Орманова четверо сыновей: Юсуфгирей (на казахском еще Жусуп), Адильгерей, Шангерей, Салимгерей. Если отцом Даулетшаха Кусепкалиева является султан Юсуфгирей (как написано в архивных документах) Кусепкалиев, то отец Юсуфгирея - Кусепкали Орманов, а отцом Кусепкали Орманова был Орман, сын Нуралы хана (Касабулатова, 2014: 4-5). Сыновья Кусепкали Орманова Ахметше, Адильгерей, Шангерей, Салимгерей, Жусуп.
Кусепкали султан вместе с сыновьями, оказывал вооруженные сопротивления колониальной политике России, в 1868-70 годы участвовали в восстании казахов Младшего жуза против проведения реформ в казахской степи, осенью 1869 года - в боях с регулярными войсками подполковника Новокрещенова и фон Штемпеля вдоль реки Жем. При вмешательстве помощника начальника уезда Калмыково Омара Казиева, внука Сырым батыра, Кусепкали султан, его двоюродные младшие братья Куат и Шора Сугиралиевы, также несколько человек, участвовавшие с ними в восстании, были арестованы. Первые полтора года Кусепкали султан вместе с сыновьями провел в Уральской тюрьме, затем решением военной комиссии был сослан в Старосербск Екатеринославской губернии, но по дороге Кусепкали умирает, и тело его было захоронено в Ростове на мусульманском кладбище (ГАЗКО, 256-фонд, опись 1 , дело № 15:306).

Так сын Жусупа Даулетшах родился в городе Старосербск. Оставшиеся в живых из потомков Кусепкали султана остались в уезде Жанаозен Самарской губернии, на родину вернулись позже. Поэтому Даулетшах в 1880 году с оставшимися в живых братьями возвращается на родину отца, в окрестности Азынабай-Тайпак, пастбище Акбакай (село Саралжын Каратобинского района) (по письму Р. Касабулатовой).

\section{Профессиональный рост}

Также Р. Касабулатовой была дана копия письма, где подписями 96 человек, родовым знаком, печатью волостного управления Улента-2 действительно подтверждались родословные корни Даулетшаха Кусепкалиева. В письме приведены данные из его биографии. В приговоре о сословии, написанном 16 июня 1895 года 96 жителями волости Уленты №2 Калмыковского уезда Уральской области, принято решение о переводе в ранг султана Даулетшаха Кусепкалиева, окончившего с серебряной медалью за особые успехи в учении и дисциплину. По их словам, Даулетшах Кусепкалиев считается прямым потомком хана всей Младшей Орды Султана Нуралы хана (ГАЗКО, 4-фонд, опись 1, дело № 558:31).

Даулетшах Кусепкалиев обучился грамоте в волостной русско-казахской школе. Затем в 1887 году, поступив в мужскую классическую гимназию г. Оренбурга, окончил ее 8 июня 1895 года с серебряной медалью. 
Даулетшах Кусепкалиев - один из первых образованных врачей в Казахстане, участник движения Алаш

В личном листе Даулетшаха Кусепкалиева фонда Западно-Казахстанского областного историко-краеведческого музея говорится об окончании с серебряной медалью научного курса Оренбургской классической гимназии: «Во вниманіе къ постоянно-отличному поведенію, прилежанію и къ отличнымъ успъхамъ въ наукахъ Педагогическій Совъть постановил наградить его Кусябгаліева, серебряною медалью и выдать ему аттестатъ зрълости, предоставляющій ему всъ права, обозначенныя въ № 130-132 ВЫСОЧАЙШЕ утвержденнаго 30 Іюля 1871 г. Устава гимназій и прогимназіи въдомства Министерства Народнаго Просвъщенія Оренбургъ, Іюня 8 дня 1895 года».

1 июля 1895 года по окончании Оренбургской классической гимназии с серебряной медалью Даулетшах Кусепкалиев пишет на имя ректора Московского императорского университета заявление с просьбой зачислить его на медицинский университет и обязуется добросовестно выполнять все правила и постановления университета. 1 июля 1895 года зачисляется в Московский императорский университет (ГАЗКО, 256-фонд, опись 1, дело № 15:19).

Врач Даулетшах Кусепкалиев, окончив данное учебное заведение 12 июня 1900 года, в сентябре-октябре 1900 года проходит медицинскую экспертную комиссию при медицинском факультете императорского Московского университета. По решению Государственного Сoвета удостаивается высокой оценки, 14 октября 1900 года Даулетшах получает звание лекаря со всеми привилегиями и правами. Спустя немного времени Даулетшах Кусепкалиев получает звание врача, о чем в свидетельстве написано: «Отъ Съвета Императорского Московского Университета Лькарю Давлетшаху Кусябгаліеву дано сіе свидътельство въ томъ, что онъ, по надлежащемъ, испытаніи въ Медицинскомъ Факультетъ о предъленіемъ Университетского Совъта 16-го декабря 1900 года состоявшимся, утвержденъ въ званіи Уъздного Врача ...».

О присуждении квалификации «Лекарь» написано в дипломе № 911.

В свидетельстве об окончании Даулетшахом Московского императорского университета указано, по каким направлениям им получены знания: «Предьявитель сего Кусябгаліев Давлетшахъ Юсуфгиреевъ, Магометанского въроисновъданія, сынъ Султана из Киргизовъ родившійся 23 августа 1874 года въ Калмыков. У. Уральской обл, по аттестату зрълости Оренбургской гимназіи съ серебряною меда- лью принять быль въ число студентовъ ИМПЕРАТОРСКОГО Московского Университета въ Іюль 1895 года и зачисленъ на медицинскій факультетъ, на которомъ слушаль курсы: по зоологіи, ботаникъ, минералогіи, физикъ, неорганической химіи, органической химіи, медицинской химіи, по анатоміи здороваго человека, по физіологіи, по гистологіи и эмбриологіи, по фармакогнозіи и фармаціи, по фармакологіи съ рецептурою и бальнеологіей, по общей патологіи, по анатоміи и гистологіи патологической, по врачебной діагностикъ и про педевтической клиникъ, по десмургіи и ученію о переломахъ и вывихахъ, по частной патологіи и терапіи, по нервнымъ болезнямъ и психіатріи съ клиниками, по кожнымъ и венерическимъ болезнямъ съ клиникою, по хирургической патологіи, факультетской хирургической клиникъ, по болезнямъ мочевыхъ и половыхъ органовъ съ клиникою, по факультетской терапической клиникъ, по оперативной хирургіи и хирургической анатоміи, по госпитальной терапической клиникъ, по офталміатріи съ клиникою, по акушерству, съ клиникою, по женскимъ болезнямъ съ клиникою, по дътским болезнямъ съ клиникою, по судебной медицинъ и медицинской помощіи, по гигіенъ со статистикою, по исторіи медицины и эпизоотологіи съ ветеринарною полиціей, участвовал въ установленныхъ учебнымъ планомъ практическихъ занятіяхъ; подвергался полукурсовому испытанію изъ 1-й части въ 1896 году изъ 2-й части въ 1897 году...» (ГАЗКО, 256-фонд, опись 1, дело № 15:19).

Будучи студентом, Даулетшах Кусепкалиев получал стипендию от управления Уральского военного казачества. По некоторым сведениям, параллельно обучившись на юридическом факультете данного вуза, получил одновременно два диплома.

На формирование общественно-политических взглядов Д. Кусепкалиева, безусловно, повлияли, с одной стороны, общественно-политические события в России, где он учился, и с другой - социально-экономическая и политическая жизнь казахского общества, откуда он и вышел. Обмен опытом между такими же ведущими русскими врачами, как и он сам, участие в коллегиальных собраниях способствовали обогащению врачебного опыта, профессиональному росту и развитию политического мышления. Отдельные личности как общественно-политические деятели, находясь в гуще всех событий, сыграли важную роль в историческом процес- 
се. При решении государственных вопросов не смогли не повлиять на Д. Кусепкалиева и эти общественные явления.

По словам Р. Касабулатовой, когда в 1919 году ее отец Е. Касабулатов и еще несколько человек попали в руки атамана А.У. Дутова, именно Даулетшах, лично встретившись с Дутовым, помог им выйти на свободу.

В начале врачебной деятельности Даулетшаха состояние здравоохранения Казахстана было низким, так как Казахстан до Октябрьской революции в экономическом и культурном отношении был одним из отдаленных регионов российского царства. Во второй половине XIXначале XX вв. кочевое хозяйство казахов стало испытывать сильное воздействие внешних экономических факторов со стороны развивавшейся капиталистической России. Образовались новые формы хозяйства: оседло-скотоводческая и оседло-земледельческая. В процессе их сложения возникали самые разнообразные переходные формы хозяйства. Тяжелые условия быта, нелегкая жизнь, отсутствие медицинской помощи - все это способствовало распространению и обострению различных болезней среди трудящихся масс.

Жизнь шаруа-крестьян, которые, не покладая рук, должны были зимой и летом пасти байский скот, была самой тяжелой и жалкой. В связи с этим различные инфекционные заболевания, в том числе передающиеся от животных, приносили много несчастья. Особенно часто встречались такие болезни, как бруцеллез, туберкулез, сибирская язва, бешенство, туляремия и другие, причину возникновения которых видели в несоблюдении санитарно-гигиенических условий. Несмотря на их широкое распространение, медицинская помощь на должном уровне не оказывалась, так как царское правительство не обращало внимания на развитие медицины в казахской степи, которая была ей в качестве колониальной окраины.

В такое нелегкое время, в 1895 году, Д.Кусепкалиев назначается врачом 2-медицинского сельского участка Лбищенского уезда Уральской области, оказывает врачебную помощь в волостях Карагаш, Улента, Жымпиты, Соналы, Калдыгайты (ГАЗКО, 256-фонд, опись 1, дело № 15:19).

В 1898 году на всю территорию Западного Казахстана с площадью 585894 квадратных километра с численностью 587446 человек приходилось всего 11 врачей, 28 фельдшеров, 7 акушеров (Душманов, 2000: 139).
В 1913 году в казахской степи было всего 98 больниц (1800 койко-мест), 96 амбулаторий, т.е. на 14 тысяч кв.м. приходилось по одному медицинскому учреждению. Число врачей в Казахстане не доходило до 200, причем большая часть которых работала в городах. Эти показатели еще раз подтверждают, что необходимая медицинская помощь на должном уровне не оказывалась. В связи с этим инфекционные заболевания захватили население, особенно была высока детская смертность. Так, если в 1913 году в Приуралье в год родилось 7654 ребенка, то число случаев смерти детей в этом же году доходило до 7702-х, т.е. показатели смертности превышают число родившихся. Это объясняется малым количеством врачей среди казахов, русские же не понимали состояние населения, к тому же не были заинтересованы ехать работать в степь (Душманов, 2000:145).

До октябрьской революции в сельских местностях Западного Казахстана, как и в большинстве регионов Казахстана, не было санитарных пунктов. Только начиная со второй половины XIX века, после реформ 1867-1868 гг. в целях обслуживания населения впервые были определены должности уездного врача, уездного фельдшера и акушера. Но не во всех регионах были организованы уездные медицинские учреждения. Поэтому открываемые в то время фельдшерские пункты были подобны капле в море. Они не смогли покрыть даже самые минимальные нужды населения в сфере здравоохранения. В такое тяжелое для Казахстана время активно приступает к работе во благо своего народа Д. Кусепкалиев, получивший медицинское образование в России.

Основным видом медицинской службы этого времени в Западном Казахстане была земская медицина. Согласно распоряжению Государственного Совета «О делении уездных медицинских отделов Тургайской и Уральской областей на медицинские участки» от 8 июля 1898 года с 1899 года врачебные участки земской медицины стали формироваться и в Уральской области. С 1 января 1899 года согласно введенной штатной численности Уральская область делится на 11 врачебных участков. В каждый участок были выделены врач, фельдшер и фельдшер-акушер. В это время сразу после окончания университета Д. Кусепкалиев направляется врачом в участковую больницу (на 25 коек) Жымпитинского уезда Уральской губернии. Жымпитинская больница является одной из первых трех больниц, открывшихся на казахской земле (в 1894 году). 
Даулетшах Кусепкалиев - один из первых образованных врачей в Казахстане, участник движения Алаш

Тогда при отсутствии на участках врачей с высшим образованием работали медики среднего звена. Первый врач-казах, получивший высшее образование, Даулетшах Кусепкалиев в 1896 году начинает трудовую деятельность в больнице. Тогда уезд Жымпиты охватывал 36 волостей. В это время санитарное состояние края было очень тяжелым. Главные причины смертности населения - малярия, чума, тиф и отсутствие медицинской помощи в лечении. Только в Уральской области в 1899 году зафиксирован 1691 случай заболевания сифилисом. В журнале «Обзор Уральской области 1899 года» отмечено, что «К сожалению, быстрому распространению этого заболевания среди киргизского народа способствуют: 1) кочевой образ жизни киргизов и их тесное взаимодействие друг с другом; 2) неинформированность народа о причинах возникновения этого заболевания и его инфекционного периода; 3) нечистоплотность в быту, связанная с недостатком воды в киргизской степи; 4) недостаточная организация больничной помощи населению» (Душманов, 2000: 60).

Благодаря предложениям Д. Кусепкалиева, находящегося в самом центре такой ситуации, и таких врачей, как Т.Кудайкуов, С.Қазиев, А.Маликов, работавших с ним вместе, в 1899 году Жымпитинская киргизская общественная больница передается управлению областного киргизского земства. Если в год на содержание этой больницы выходило 4750 рублей, то заработная плата врача составляла 800 рублей, фельдшера - 300 рублей, фельдшера-акушера - 360 рублей (Энциклопедия, 2000: 47).

Таким образом, Д. Кусепкалиев находится в центре всех работ по медицинскому обслуживанию населения края. Приехав врачом на родину в село Тайпак, в 1902 году способствует открытию первой в этом краю небольшой больницы, где ведет плодотворную работу. Был единственным врачом на всей территории Тайпака.

В 1903 году направляется врачом в такие волости 2-участка Гурьевского уезда Уральской области, как Улента, Кызылкога, Ойыл, Сурели, Есбол, Карабау, Сламихын, Керимакас, Кайыгайшы, Жымпиты, Киыл и др., также был крестьянским начальником на участке, опекуном-попечителем Кермекасского одногодичного русско-казахского училища. Там Даулетшах наряду с врачебной деятельностью вносит большой вклад в обучение грамоте простых казахов. Является одним из активных деятелей, способствующих открытию двухгодичной русско-киргизской школы в Керимакасе. Такая особая опека в сфере образования была связана с пониманием сути проблемы, на каком уровне образование местного населения по сравнению с другими представителями казахской интеллигенция того времени. Наряду с врачебной деятельностью Даулетшах оказал большое влияние на распространение русского языка среди казахов. Женится на дочери младшего брата видного казахского акына Шангерея, Айше.

В 1912 году назначается заведующим Жымпитинской земской больницы. С этой больницей связано «нашумевшее» событие - крушение Царского поезда, которое случилось 17 октября 1888 года на станции Борки линии Курск - Харьков - Азовск. В честь благополучного исхода этого события был сформирован Комитет по созданию благотворительных организаций, которые открываются как в самой России, так и в ее регионах. Так, Жымпитинская больница является результатом данной акции.

Наряду с заведованием Жымпитинской земской больницей в 1912 году он получает должность крестьянского начальника. Используя финансы областного земства, способствовал открытию при больнице отдела по лечению больных неврологического характера и родильного дома. Являясь заведующим Жымпитинской земской больницы, в 1912 году вместе с врачом Н.А.Селезневым активно участвует в работе по профилактике и ликвидации очага чумы. Открываются временная противочумная лаборатория и склад хранения медикаментов против чумы (Caмарин, 1958: 31).

В то время Жымпитинская больница функционировала за счет финансирования земства. Наряду с заведованием больницей, с лечением больных он выступает инициатором в осуществлении мер по предупреждению болезней. Особенно важную роль сыграл в борьбе с чумой, оспой.

В 1914 году Даулетшах направляется заведующим в строящуюся Тайпакскую больницу. Несмотря на плохое состояние своего здоровья, не жалеет сил в оказании медицинских услуг населению. Входит в состав киргизского революционного комитета. После долгое время руководит областной санэпидемстанцией в городе Уральске. По состоянию здоровья просит киргизский революционный комитет вновь перевести его в Жымпитинский уезд. «Просим сообщить о выезде из Уральска врача Уральского областного революционного комитета Д. Кусепкалиева. После него уезд остался без врача» написано в телеграмме от 19 июня 1920 г., от- 
правленной председателем ревкома Е. Касабулатовым.

В связи с окончанием стройки строительства больницы он возвращается в Жымпиты. Здесь продолжает свою деятельность по обслуживанию населения. Основная направленность его работы заключалась в борьбе с широко распространенными среди народа инфекционными заболеваниями, так как в 1915 году в Западном Казахстане было зарегистрировано случаев заболевания чумой 116 , холерой - 92 (Ауанасова, 1993: 87). Борьба с этими болезнями велась силами местных врачей. Поэтому роль Кусепкалиева как лечащего врача ряда волостей Западного Казахстана велика. Доказательством тому, как трудился врач Жымпитинской больницы Даулетшах в 1915 году во время обострения чумы на территории волости, пишет исполняющий обязанности медицинского инспектора, видный деятель здравоохранения Западного Казахстана А.В. Гекке: «Бытовые условия медицинских работников во время эпидемии чумы были на очень низком уровне, не хватало необходимой мебели. Некачественное питание, жесткая вода способствовала развитию болезни желудка. Передвижение с одного места на другое пешком или на арбе негативно влияли на здоровье врача. Создание условий медицинским работникам на очень низком уровне» (ГАЗКО, 256-фонд, опись 1, дело № 15:12).

В ходе его активной деятельности объем оказываемой медицинской помощи киргизской больницы Жымпитинского земства увеличивается на 35 коек. Вместе с саратовским врачомэпидемиологом Г.Кольцовым впервые в казахской степи организовал лабораторию по борьбе с чумой, провел работу по прививке против инфекционных заболеваний. В 1914 году, приняв участие в областном съезде по борьбе с чумой, проходившем в городе Самаре, выступил с всесторонним докладом. Этому событию Миржакып Дулатов посвятил статью, которая была опубликована в газете «Қазақ». Также Даулетше Кусепкалиев - один из тех, кто поддерживал газету «Қазақ» своими статьями, за что в 1914 году в №45 руководство газеты, наряду с другими гражданами, выразило ему благодарность.

Д. Кусепкалиев, как и другие врачи Внутренней (Букеевской) киргизской орды, принимает участие в работе ряда съездов против чумы, проводимых в соседних губерниях России. С первым своим докладом на тему «Возникновение чумы в Уральской области» (61 страница) он выступил в 1910 году в Астрахани на «съезде участников против чумы в Астраханской губернии и Уральской области». О работе этого съезда и опасной для населения на тот момент проблеме чумы напечатано в №2 «Вестника общества врачей Астрахани». А второй доклад на тему «О мерах профилактики чумы» был сделан в 1914 году на съезде в г.Самаре и опубликован в 1914 году в сборнике «Труды съезда по борьбе с чумой в г.Самаре» (Душманов, 2000: 175). В своих докладах Д. Кусепкалиев с научной точки зрения обосновывает необходимость организации в казахской степи пунктов медицинского контроля, что способствует открытию в скором времени в казахской степи медицинских контрольных пунктов, пополнению рядов врачей.

Так, в 1899-1915 годы при объединении двух уездов Уральской и Тургайской областей объем оказываемой врачебной деятельности достигает следующих показателей (Душманов, 2000: 64):

\begin{tabular}{|c|c|c|c|c|}
\hline Годы & $\begin{array}{c}\text { Коли- } \\
\text { чество } \\
\text { врачей }\end{array}$ & $\begin{array}{c}\text { В том числе } \\
\text { сельских } \\
\text { урастовых } \\
\text { врай }\end{array}$ & $\begin{array}{c}\text { Количество } \\
\text { земских } \\
\text { больниц и } \\
\text { приемных } \\
\text { отделений }\end{array}$ & $\begin{array}{c}\text { Коли- } \\
\text { чество } \\
\text { кроватей } \\
\text { в них }\end{array}$ \\
\hline 1899 & 35 & 17 & 9 & 60 \\
\hline 1905 & 35 & 17 & 12 & 76 \\
\hline 1908 & 33 & 15 & 13 & 106 \\
\hline 1912 & 45 & 17 & 21 & 153 \\
\hline 1913 & 48 & 16 & 21 & 168 \\
\hline 1914 & 51 & 15 & 21 & 193 \\
\hline 1915 & 67 & 19 & 21 & 204 \\
\hline
\end{tabular}

Малое количество врачей в краю объяснялось следующими причинами: 1) незаинтересованностью имперской администрации в получении образования народов национальных окраин; 2) неимением у большинства казахской молодежи законченного гимназийского образования и отсутствием возможности получения медицинского образования в университетах; 3) небольшим количеством русских врачей, соглашавшихся ехать работать в казахскую степь. Тем не менее в 1915 году в Западном Казахстане только из казахов было всего 6 врачей, 26 фельдшеров, в том числе 2 врача и 13 фельдшеров было во Внутренней (Букеевской) орде (Душманов, 2000:65).

Одним из основных направлений работы Д. Кусепкалиева при оказании медицинской по- 
мощи являлась организация помощи лекарствами. По данным Западно-Казахстанского государственного архива, в 1913 году в Казахстане, наряду с тремя работавшими на добровольной основе и одной государственной аптек, в Калмыкове, Жымпиты и в других селах функционировало еще 8 аптек. Местные врачи доставляли лекарства населению из этих аптек.

Большое влияние на формирование Д. Кусепкалиева как врача-эпидемиолога оказало его участие в работе съездов, совещаний Общества врачей соседних губерний России, посвященных проблеме борьбы с чумой, в ходе которых он встречался и обменивался опытом с такими видными врачами, как Н.Н. Клодницкий, И.А. Деминский, С.М. Никаноров и др. Полученные знания и опыт Даулетшах использует на практике по улучшению состояния здоровья казахского народа.

\section{Новый этап деятельности}

С 1917 года начинается новый этап в деятельности Д. Кусепкалиева. Он активно участвует в политических событиях, имевших место после февральского переворота. После свержения царя в феврале 1917 года, не оставаясь в стороне от общественно-политической ситуации, вместе с интеллигенцией, стоявшей во главе казахского народа, поддерживает идею формирования нового общества. В связи с этим Д. Кусепкалиев вступает в состав казахского Комитета Уральской области, сформированного в рамках 1-го съезда казахов Зауралья, проведенного 19-22 апреля 1917 года в городе Уральске.

Он был создан в конце мая 1918 года решением IV Уральского областного казахского съезда, проведенного в Жымпиты. Даулетше Кусепкалиев избирается одним из 7 человек в состав Временного правительства «Ойыл уалаяты» (ГАЗКО, 4-фонд, опись 1, дело № 558: 22).

После установления Советской власти на казахской земле Кусепкалиев с марта по июль 1920 года является заведующим санитарно-эпидемиологического отделом управления киргизского края в сфере здравоохранения революционного комитета г. Оренбург. Одним из его единомышленников в этой сфере был его зять Есенгали Касабулатов. В те времена, несмотря на трудную ситуацию среди населения, они широко проводили санитарно-эпидемиологические и оздоровительные мероприятия. Согласно своему заявлению и по просьбе председателя Уральского губревкома, зятя Есенгали Касабулатова, в июле
1920 года направляется заведующим в Жымпитинскую уездную больницу.

В 1921 году после перевода Есенгали Касабулатова в Оренбург был направлен заведующим медицинским участком в Тайпак.

На самом деле мероприятия по борьбе с инфекционными заболеваниями не остаются вне внимания Кусепкалиева. В мае 1923 года на Региональном Совете по созданию противочумного центра в Саратове, где принимали участие и представители Уральской области, было принято решение о формировании комиссии против чумы с центром в Саратове.

В октябре 1925 года возвращается в Жымпиты на должность заведующего городской больницы. По словам врача Даулетшаха Кусепкалиева, с ноября 1925 года по сентябрь 1926 года работал в Тайпакской участковой больнице, с января 1926 года - в Жымпитинском уезде, в 1926-1927 годы - в населенном пункте Тайпак (Ауанасова, 1993:13).

В 1928-1929 гг. во времена начала конфискации и принудительного перевода населения на оседлый образ жизни смело выходит против этой кампании. В связи с этим в ноябре 1929 года по обвинению «за участие в составе группы Меңдешова» был освобожден от работы и подвергнут конфискации по двум категориям - «полуфеодал» и бывший деятель Алашорды, затем отправлен в ссылку в Жетысуский округ в составе 113 баев. В 1929-1934 гг. работает врачом в республиканском венерологическом диспансере в Алма-Ате, куда был устроен благодаря приглашению Ахмета Маметова, заведующего данным диспансером, который был женат на дочери его младшего брата Сулеймена, Амине. Также преподает в сельскохозяйственном университете в Алма-Ате. В 1934-1940 гг. работает главным врачом Каскеленской районной больницы Алматинской области, Келесской районной больницы Южно-Казахстанской области, Абайской районной больницы Семипалатинской области. В эти годы Даулетшах широко известен как квалифицированный специалист, видный врач, который вложил все свои знания и силы в развитие здравоохранения. В 1944 году умирает в Семилатинской области, где работал в последние годы жизни.

\section{Заключение}

В настоящее время работа по исследованию жизни и деятельности Д. Кусепкалиева продолжается, в этом году в результате беседы с его 
внучкой Раисой Касабулатовой, дочерью Гайнижамал и Есенгали Касабулатовых, получено много сведений. Раиса Касабулатова (1935 года рождения), проживающая в Москве, во время беседы с нами передала хранившиеся у себя архивные документы и записала воспоминания, услышанные ранее от родителей. Также Раиса Касабулатова рассказала о встрече со своим дедом Даулетшахом, которая произошла в 1940 году в Алма-Ате. Отец же ее, Есенгали, был арестован в августе 1937 года в Алма-Ате, затем был отправлен в Москву. После его никто не видел, затем пришла весть о его расстреле. А ее мать Гайнижамал в 1937 году, лишив свободы на два года, с 6 детьми отправили в ссылку.

Эти преследования длились в течение 10 лет. Первый лагерь - село Михайловское Жамбулского района, второй - отделение имени 1 Мая села Мактаарал (написано Пахта-Арал) Чимкентской области, затем третий - село Абай-базар Келесского района, и так продолжаются притеснения, издевательства, насилие. В третьем лагере встречается со своим дедом Д. Кусепкалиевым, который в это время работал здесь в санитарной команде. Обвинители, мучая Гайнижамал, заставляли страдать и всю семью Даулетше. Не выдержав испытаний, умирает супруга Даулетшаха, Айша, вслед за которой уходит из жизни и сам Даулетшах. После 1937 года в живых остаются лишь младший сын Даулетшаха (по словам Р.Касабулатовой, его ласково звали Зипуша), младшая дочь София и старшая дочь Гайнижамал с детьми, также жена старшего сына Сара Кашкынбаева (невестка). В 1950 году Гайнижамал с двумя дочерьми отправляют в ссылку на 6 месяцев в Усть-Каменогорск. Затем их отправляют в Зыряновск, а младший сын Даулетшаха и вернувшийся из войны живым Шамиль, сын Е. Касабулатова, тоже были сосланы в Восточно-Казахстанскую область. Раиса, уехав в Москву в 1956 году, до сих проживает там. Гайнижамал вместе со старшей дочерью в 1956 году получают разрешение жить в Алма-Ате. Старший же сын Даулетшаха остается на сосланной земле до конца своих дней. Дети Даулетшаха были реабилитированы лишь в 1989 году.

Так трагически сложилась судьба человека, одного из первых образованных казахских врачей, общественного деятеля, который в начале $\mathrm{XX}$ века в тяжелое для народа время боролся за достойную жизнь нации, провозглашал свободу и равенство, внес большой вклад в будущее страны и является примером для подражания следующим поколениям.

В настоящее время научно-исследовательская работа продолжается, надеемся, что можно будет добиться новой дополнительной информации об общественных деятелях из его окружения, их потомках, фото из семейных архивов и других документов.

\section{Литература}

Ауанасова А. (1993). Национальная интеллигенция Казахстана в первые годы Советской власти (1917-1927 гг.): Автореф. дисс. ... к. и. н. - Бишкек. 23 с.

Аманжолова Д.А. (2009). На изломе. Алаш в этнополитической истории Казахстана. Алматы: Издательский дом «Таймас». $412 \mathrm{c}$.

Госархив Западно-Казахстанской области, 4-фонд, опись 1, дело № 309.

Госархив Западно-Казахстанской области, 256-фонд, опись 1, дело № 15.

Госархив Западно-Казахстанской области, 4-фонд, опись 1, дело № 558.

Душманов С.Х. (2000). Очерки истории медицины и здравоохранения Казахстана. Актобе: Раст. 75 с.

Из личного архива Р.Касабулатовой, внучки Д. Кусепкалиева.

Из письма воспоминаний Р. Касабулатовой.

«Приговор о сословиі» архивные документы, полученные от Р. Касабулатовой (листы 5,6,7,8).

Самарин Р.И. (1958). Очерки истории здравоохранения Казахстана. Алма-Ата: Казгосиздат. С.162

Саяси қуғын-сүргіндер және олардың зардаптары. Естеліктер мен мақалалар жинағы - Политические репрессии и их последствия. Сборник воспоминаний и статей (2009). Сост. Е.М.Грибанова, Г.Н.Мурзагалиева, Е.В.Чиликова. Алматы: Архив Президента Республики Казахстан. 158 с.

Сулейменова. Д. (2007). История Западного отделения Алаш-орды - составная часть истории края. / Д. Сулейменова Алматы: Издательство «Арыс». С. 142-147.

Энциклопедия. (2002). Западно-Казахстанская область. Алматы: Издательство «Арыс». 592 с.

\section{References}

Auanasova A. (1993). Natsional'naya intelligentsiya Kazakhstana v pervyye gody Sovetskoy vlasti (1917-1927 gg.) Avtoref. diss. ... k. i. n. [The national intelligentsia of Kazakhstan in the early years of Soviet power (1917-1927)]. Bishkek. 
Amanzholova D.A. (2009). Na izlome. Alash v etnopoliticheskoy istorii Kazakhstana. [At the break. Alash in the ethnopolitical history of Kazakhstan. Almaty: Taymas Publishing House]. Almaty: Izdatel’skiy dom «Taymas».

Gosarkhiv Zapadno-Kazakhstanskoy oblasti, 4-fond, opis’ 1, delo № 309. [State [Archive of West Kazakhstan region, 4-fund, description 1, case number 309].

Gosarkhiv Zapadno-Kazakhstanskoy oblasti, 256-fond, opis’ 1, delo № 15. [State Archive of the West Kazakhstan region, 256fund inventory 1 , case number 15].

Gosarkhiv Zapadno-Kazakhstanskoy oblasti, 4-fond, opis’ 1, delo № 558. [State Archive of the West Kazakhstan region, 4-fund inventory 1 , case number 558].

Dushmanov S.KH. (2000). Ocherki istorii meditsiny i zdravookhraneniya Kazakhstana. [Essays on the history of medicine and health in Kazakhstan]. Aktobe: Rast.

Iz lichnogo arkhiva R.Kasabulatovoy, vnuchki D. Kusepkaliyeva. [From the personal archive of R. Kasabulatova, granddaughter of D. Kusepkaliyev].

Iz pis'ma vospominaniy R. Kasabulatovoy. [From a letter of memoirs of R. Kasabulatova].

«Prigovor o soslovií» arkhivnyye dokumenty, poluchennyye ot R. Kasabulatovoy (listy 5,6,7,8) [«The sentence of estate» archival documents received from R. Kasabulatova].

Samarin R.I. (1958). Ocherki istorii zdravookhraneniya Kazakhstana. [Essays on the history of health in Kazakhstan]. AlmaAta: Kazgosizdat.

Sayasi kuġyn-syrgínder zhane olardyn zardaptary. Yestelíkter men makalalar zhinaġy - Politicheskiye repressii i ikh posledstviya. Sbornik vospominaniy i statey (2009). Sost. Ye.M. Gribanova, G.N. Murzagaliyeva, Ye.V. Chilikova. Almaty: Arkhiv Prezidenta Respubliki Kazakhstan. [Political repression and their consequences. Collection of memoirs and articles / E.M. Gribanova, G.N. Murzagaliyeva, E.V. Chilikova. Almaty: Archive of the President of the Republic of Kazakhstan].

Suleymenova. D. (2007). Istoriya Zapadnogo otdeleniya Alash-ordy - sostavnaya chast' istorii kraya. / D. Suleymenova. [The history of the Western branch of Alash-Orda is an integral part of the history of the region]. Almaty: Izdatel'stvo «Arys».

Entsiklopediya (2002). Zapadno-Kazakhstanskaya oblast'. [West-Kazakhstan region]. Almaty, Izdatel'stvo «Arys». 